\title{
Somatic development and embryo yield in crossbred F1 mice generated by different mating strategies
}

\author{
Batista, RITP. ${ }^{\mathrm{a}}$, Wohlres-Viana, S. ${ }^{\mathrm{b}}$, Pinto, ISB. ${ }^{\mathrm{c}}$, Maffili, $V V^{\mathrm{d}}$ and Viana, JHM. ${ }^{\mathrm{a}, \mathrm{e} *}$ \\ ${ }^{a}$ Centro de Ensino Superior de Juiz de Fora - CES/JF, \\ CEP 36016-000, Juiz de Fora, MG, Brazil \\ ${ }^{b}$ Universidade Federal de Juiz de Fora - UFJF, \\ CEP 36016-970, Juiz de Fora, MG, Brazil \\ 'Universidade Federal de Viçosa - UFV, \\ CEP 36570-000, Viçosa, MG, Brazil \\ ${ }^{d}$ Centro de Pesquisa Gonçalo Moniz, Fundação Oswaldo Cruz - Fiocruz, \\ CEP 40295-001, Salvador, BA, Brazil \\ ${ }^{\circ}$ Empresa Brasileira de Pesquisa Agropecuária - Embrapa Gado de Leite, \\ CEP 36038-330, Juiz de Fora, MG, Brazil \\ *e-mail: jhmviana@cnpgl.embrapa.br
}

Received July 3, 2008 - Accepted February 9, 2009 - Distributed February 28, 2010

(With 2 figures)

\begin{abstract}
The aim of this study was to evaluate different mating strategies among endogamic strains to create F1 populations of mice, minimising the effect of inbreeding depression on somatic development and embryo yield. Females from the strains Swiss, CBA and C57B1/6 were divided in nine experimental mate arrangements. The total numbers of pups born alive per dam and somatic development, estimated by weighing and measuring the crown-rump length, were recorded. Superovulation response was evaluated in outbreed females. Litter size differed among endogamic dams, irrespective of the sire. Somatic development results suggest heterosis and imprinting phenomena, once a differential parental effect was demonstrated. There was no difference in corpora lutea, ova or embryos recovered $(\mathrm{P}>0.05)$, but recovery and viability rates differ among $\mathrm{F} 1$ groups $(\mathrm{P}<0.05)$. The association of dam prolificity with somatic development and superovulation response of the pups should be considered for experimental F1 populations establishment. The use of outbreed animals, however, did not reduce response variability to hormone treatment.
\end{abstract}

Keywords: embryo, endogamy, imprinting, mice, strains.

\section{Desenvolvimento somático e produção de embriões em camundongos cruzados $\mathrm{F} 1$ gerados com diferentes estratégias de cruzamento}

\begin{abstract}
Resumo
Objetivou-se neste estudo avaliar diferentes estratégias de cruzamento entre linhagens endogâmicas para a formação de populações de camundongos F1, minimizando o efeito da depressão por endogamia nos resultados de desenvolvimento somático e produção de embriões. Fêmeas das linhagens Swiss, CBA e C57Bl/6, foram distribuídas em nove possíveis cruzamentos. Foram registrados o número de filhotes nascidos vivos por matriz e o desenvolvimento somático dos mesmos, mensurado pelo peso e comprimento. A resposta superovulatória foi avaliada nas fêmeas cruzadas. O tamanho das ninhadas diferiu entre as linhagens das matrizes, de forma independente da linhagem dos reprodutores. Os resultados do desenvolvimento somático sugerem a ocorrência de heterose e imprinting, uma vez que foi demonstrado um efeito parental diferenciado. Não foram observadas diferenças no número de corpos lúteos, estruturas ou embriões recuperados $(\mathrm{P}>0,05)$, mas as taxas de recuperação e o percentual de embriões viáveis diferiram entre os grupos $(\mathrm{P}<0,05)$. A associação da prolificidade da linhagem das matrizes com as características do desenvolvimento somático e resposta superovulatória dos filhotes deve ser considerada no estabelecimento de populações experimentais F1. O uso de animais cruzados, contudo, não reduziu a variabilidade da resposta aos tratamentos hormonais.
\end{abstract}

Palavras-chave: camundongos, embrião, endogamia, imprinting, linhagens. 


\section{Introduction}

Mice have been extremely important as an animal model in scientific research, due to the wide range of possible applications, consistency of results and low cost. They can be used for the most variable purposes, from basic research to the development of products for commercial application, being particularly important in human and animal health (Andrade et al., 2006). Murine embryos have been extensively used in developmental biology studies, including fertilization, embryo development, differentiation, morphogenesis and organogenesis (Dieterlen-Lievre et al., 2005). Their use in biotechnics development (e.g., chimerism, cloning and transgenesis) was essential and mice embryos are also the main model for media and material quality evaluation in this area (Eakin and Hadjantonakis, 2006).

The vivarium population is composed mainly of colonies of animals generated by inbreeding crosses and, as a result, highly endogamic (called inbreed). The colonies are established with the purposes of self-propagation and generation of animals for experimentation. The use of inbreed colonies present the advantage of genetic homozigocity (or isogenicity), which means that all individuals are virtually genetically identical, leading to a uniformity of the inheritable traits (Braggio et al., 2003).

Despite their advantages, endogamic crosses can have deleterious effects by enabling the expression of recessive genes. Consanguinity reduces genetic variability, as well as in the phenotypic values, phenomena known as inbreeding depression (Holt et al., 2005). Genetic selection for economically important traits, extensively used in animal production, increases genetic gains but also results in endogamy, with depression in selection effectiveness and, in the long term, genetic diversity. Inbreeding depression causes deficiencies in growth, production, health, fertility and survival (Notter, 1999; Thompson et al., 2000; Mc Parland et al., 2007). Endogamy also negatively affects several reproductive traits, including sexual maturity, prolificity, testicular diameter and ovarian follicular reserve, and consequently embryo yield (Falcão et al., 2001; Alvarez et al., 2005).

An option to overcome the negative effects of endogamy in somatic and reproductive parameters in mice experimental groups would be the production of outbreed populations specifically for this aim. Davis et al. (1991) demonstrated the effect of heterosis on reproductive performance of mice in different environments, using a factorial crossing design. The aim of this study was to evaluate different mating strategies among endogamic strains to create $\mathrm{F} 1$ hybrid populations of mice, minimising the effect of the inbreeding depression in somatic development and embryo production.

\section{Material and Methods}

Mice from the strains Swiss, C57B1/6 and CBA were housed in proper cages, receiving water and food
(Nuvilab, CR1, Nuvital) ad libitum, and in a controlled environment of 12 hours of light and 12 hours of dark.

\subsection{Experimental design}

Young females from the endogamic strains Swiss, CBA and $\mathrm{C} 57 \mathrm{Bl} / 6,50$ days old, were divided in inter- and intra-lineages mating, in a total of nine experimental arrangements (paternal $\times$ maternal): Group 1, Swiss $\times$ Swiss; Group 2, Swiss $\times$ C57B1/6; Group 3, Swiss $\times$ CBA; Group 4, C57B1/6 × C57B1/6; Group 5, C57Bl/6 $\times$ Swiss; Group 6, C57Bl/6 × CBA; Group 7, CBA $\times$ CBA; Group 8, CBA $\times$ Swiss; e Group 9, CBA $\times \mathrm{C} 57 \mathrm{~B} 1 / 6$.

Natural mating was performed using the proportion of one female per male. The dams were subsequently transferred to motherhood cages, where they remained until weaning. Mates were performed in the same period, aiming for the formation of contemporary generations from all groups. The number of pups born alive per mated female was recorded, and the somatic development was estimated 12 days after birth by weighing with an analytical balance (Gehaka BG2000) and measuring the crown-rump length with a pachymeter.

The outbreed F1 females born were transferred after weaning to collective cages, identified by group. At the $50^{\text {th }}$ day of age, they received a conventional superovulation treatment, consisting of an I.P. administration of 5 U.I. of eCG (Novormon ${ }^{\circledR}$, Syntex S.A.), followed 48 hours later by 5 U.I. of hCG (Vetecor ${ }^{\circledR}$, Calier), both diluted in $0.1 \mathrm{~mL}$ of a sterile saline solution. Females were then allowed to mate with CBA males (due to the best reproductive performance observed in preliminary studies), also in the proportion of one female per male.

Embryos were collected from the uterine tube and uterus by flushing with DPBS solution, 72 hours after mate confirmation by visual inspection of a vaginal plug. The recovered medium was evaluated in square-lined Petri dishes, using a stereoscopic microscope (80x), to identify and classify the embryos. Morphological classification was performed according to the International Embryo Transfer Society manual (Stringfellow and Seidel, 1998).

\subsection{Statistical analysis}

Evaluated traits were submitted to the normality (Lilliefors) and homocedasticity (Bartlett) tests. Body weight and length means were submitted to analysis of variance (ANOVA), and differences among means were estimated by the Tukey test $(\mathrm{P}<0.05)$. The number of pups by paternal and maternal lineages, the number of ovulations and embryo production were analysed by the Kruskal-Wallis test. Embryo recovery and viability rates were analysed by the Qui-Square $\left(X^{2}\right)$ method. Analyses were performed using the SAEG Software (Euclides, 1982). Results were presented as mean \pm SEM.

\section{Results}

During the generation of the experimental groups, no effect of paternal lineage was observed $(\mathrm{P}>0.05)$ over 
Table 1. Average of born mice per offspring in different mates of the inbreed strains.

\begin{tabular}{lcccc}
\hline \multicolumn{5}{c}{ Maternal lineage } \\
\hline \multicolumn{1}{c}{ Paternal lineage } & Swiss & C57BL/6 & CBA & Male average \\
\hline Swiss & $8.80 \pm 0.86$ & $6.67 \pm 0.88$ & $4.00 \pm 0.58$ & $7.56 \pm 0.77^{\mathrm{x}}$ \\
C57Bl/6 & $8.75 \pm 1.60$ & $8.00 \pm 1.08$ & $4.80 \pm 0.86$ & $7.00 \pm 0.80^{\mathrm{x}}$ \\
CBA & $10.00 \pm 1.47$ & $8.00 \pm 1.00$ & $5.75 \pm 0.63$ & $7.93 \pm 0.73^{\mathrm{x}}$ \\
Female average & $9.15 \pm 0.70^{\mathrm{a}}$ & $7.69 \pm 0.58^{\mathrm{ab}}$ & $5.10 \pm 0.50^{\mathrm{b}}$ & - \\
General average & - & - & - & $7.50 \pm 0.31$ \\
\hline
\end{tabular}

${ }^{\mathrm{a}, \mathrm{b}}$ Means followed by different letter, in the same row, are different $(\mathrm{P}<0.05)$.

${ }^{\mathrm{x}, \mathrm{y}}$ Means followed by different letter, in the same column, are different $(\mathrm{P}<0.05)$.

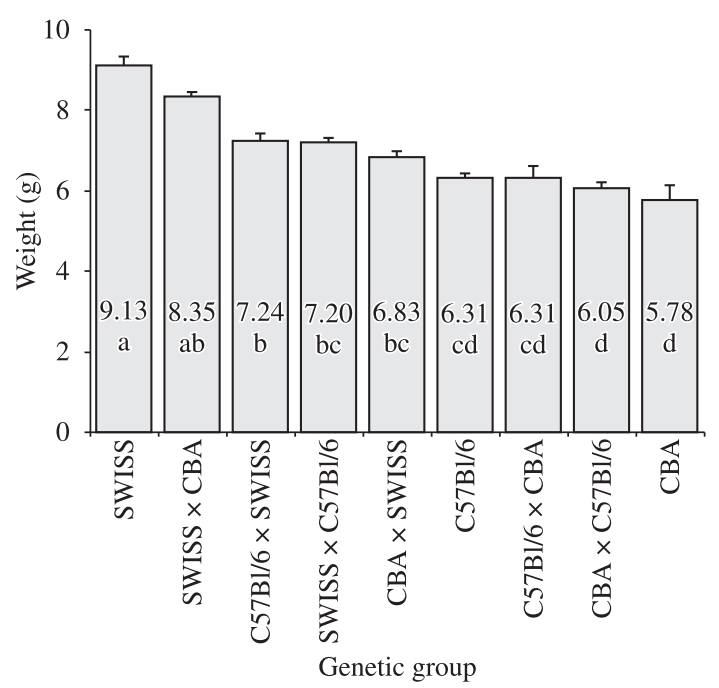

Figure 1. Mean weight of mice produced from different inbreed strains and their respective mates, at 12 days of age. In the F1 groups the paternal lineage is always indicated first. a,b,c,d means followed by different letter, in each column, are different $(\mathrm{P}<0.05)$.

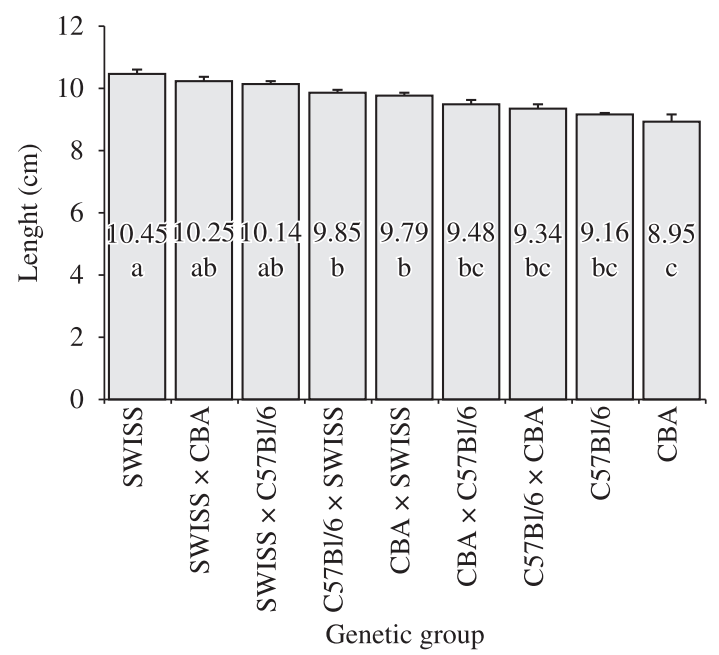

Figure 2. Mean body length of mice born from different inbreed strains and their respective mates, at 12 days of age. In the F1 groups the paternal lineage is always indicated first. a,b,c means followed by different letter, in each column, are different $(\mathrm{P}<0.05)$. offspring number (Table 1). However, among maternal lineages, the mean litter size born in the Swiss strain was greater than that observed in the CBA $(\mathrm{P}<0.05)$, and both did not differ from C57B1/6 (P > 0.05).

Results for mice somatic traits (weight and length) are presented in Figures 1 and 2. The offspring from the endogamic Swiss strain was larger and heavier $(\mathrm{P}<0.05)$ than those born from $\mathrm{C} 57 \mathrm{~B} 1 / 6$ and $\mathrm{CBA}$, which did not differ from each other $(\mathrm{P}<0.05)$. The $\mathrm{F} 1$ offspring from mates with the Swiss strain were heavier than those born from endogamic CBA and from crosses between C57B1/6 and CBA, when CBA was the paternal lineage (Figure 1). There was no difference among the outbreed crosses in relation to body length $(\mathrm{P}<0.05)$, however, the crosses in which Swiss was the paternal lineage showed a similar body length to endogamic Swiss animals (Figure 2). Inbreed and outbreed crosses with the Swiss strain also resulted in animals with greater body length $(\mathrm{P}<0.05)$ when compared with the endogamic CBA. When CBA was the paternal lineage the mate $\mathrm{CBA} \times$ Swiss exhibited a lower weight and length $(\mathrm{P}<0.05)$ when compared with endogamic Swiss, but when Swiss was the paternal lineage there was no difference $(\mathrm{P}>0.05)$.

After F1 female superovulation 521 ova were recovered, being 414 viable embryos (Table 2). The average efficiency of the superovulation treatments was $73.1 \%$, and of embryo production was $63.5 \%$, with a high correlation between the number of corpora lutea visually identified in the ovaries and the number of ova recovered $(\mathrm{R}=60.3, \mathrm{P}<0.05)$. There was no difference $(\mathrm{P}>0.05)$ in the number of corpora lutea formed, ova recovered or viable embryos, but recovery and viability rates differed $(\mathrm{P}<0.05)$ among groups. The variation coefficient for these traits ranged from 33.5 to $115.6 \%$; 70.5 to $115.6 \%$ and 76.4 to $175.6 \%$, respectively.

\section{Discussion}

The aim of this work was to evaluate different mate strategies among endogamic strains for the production of F1 mice populations. Therefore, parameters related to reproduction, somatic development and embryo yield were measured. In the generation of the experimental groups, there was an effect of the maternal, but not of the paternal lineage, on litter size. Actually, the Swiss strain presented the greater prolificity, when compared 
Table 2. Superovulatory response and embryo yield in different F1 groups (Mean \pm SEM).

\begin{tabular}{lrrrrr}
\hline \multicolumn{1}{c}{ F1 Group } & Total CL & Recovered ova & \% & Viable embryos & \% \\
\hline $\mathrm{SW} \times \mathrm{C} 57 \mathrm{Bl} / 6$ & $17.56 \pm 1.96$ & $13.63 \pm 4.23$ & $68.99^{\mathrm{b}}$ & $10.63 \pm 3.84$ & $77.98^{\mathrm{c}}$ \\
$\mathrm{SW} \times \mathrm{CBA}$ & $13.00 \pm 7.52$ & $8.75 \pm 5.06$ & $67.31^{\mathrm{b}}$ & $8.75 \pm 5.06$ & $100.00^{\mathrm{a}}$ \\
$\mathrm{C} 57 \mathrm{Bl} / 6 \times \mathrm{SW}$ & $14.62 \pm 3.44$ & $7.42 \pm 1.92$ & $46.84^{\mathrm{c}}$ & $2.50 \pm 1.18$ & $33.71^{\mathrm{d}}$ \\
$\mathrm{C} 57 \mathrm{Bl} / 6 \times \mathrm{CBA}$ & $18.13 \pm 3.19$ & $12.71 \pm 3.17$ & $61.38^{\mathrm{b}}$ & $12.29 \pm 3.11$ & $96.63^{\mathrm{b}}$ \\
$\mathrm{CBA} \times \mathrm{SW}$ & $16.13 \pm 4.19$ & $16.38 \pm 5.87$ & $101.55^{\mathrm{a}}$ & $15.63 \pm 5.79$ & $95.42^{\mathrm{b}}$ \\
$\mathrm{CBA} \times \mathrm{C} 57 \mathrm{Bl} / 6$ & $13.90 \pm 2.88$ & $9.71 \pm 3.06$ & $48.92^{\mathrm{c}}$ & $7.57 \pm 2.73$ & $77.94^{\mathrm{c}}$ \\
\hline
\end{tabular}

a,b,c,d Means followed by different letter, in the same column, are different $\left(\chi^{2} ; \mathrm{P}<0.01\right)$.

to the others strains used, a trait possibly related to a larger number of ovulations in natural cycles, since the effect was independent of the male strain used. The litter size range observed for the different strains used was similar to those reported in other studies for colonies in good health conditions (Festing, 1976; Davis et al., 1991; Kurnianto et al., 1999). The greater litter size of the Swiss dam, however, facilitates the establishment of F1 experimental populations.

Heterosis, or hybrid vigor, is characterised by trait expression or performance superior to which would be expected, considering parental breed or lineage (Nelson et al., 1990; Davis et al., 1991). This effect was not very clear for weight, a trait in which outbreed mice showed intermediate values when compared to those of the endogamic strains, but suggested for body length, with the groups $\mathrm{C} 57 \mathrm{Bl} / 6 \times \mathrm{CBA}$ and $\mathrm{CBA} \times \mathrm{C} 57 \mathrm{Bl} / 6$ showing a trend for values higher than those from the respectively inbreed strains. Precise characterisation of the heterosis effect, however, requires the standardisation of the progeny (which could not be done with the experimental design used), as litter size is negatively associated with parameters such as weight and length (Cowley et al., 1989). The CBA $\times$ Swiss mate, for example, produced the greater number of pups per dam, which may have restricted somatic development performance in this group.

Endogamic strains presented significant differences both in weight and length, with the Swiss and the CBA being the superior and inferior extremes, respectively. The greater weight of Swiss mice, when compared with the other strains, affected the development of F1 individuals generated by Swiss outbreed crosses, establishing weight differences in relation to the other groups. A differential parental effect was demonstrated, with differences in weight and length of the F1 mice in relation to the endogamic strains depending on which strain was the sire or dam. Only pups with Swiss as paternal lineage, for example, presented body length similar to endogamic Swiss ones.

The parental effect on the offspring somatic development suggests the occurrence of imprinting, with expression of paternal alleles from genes related to development, like Igf2. In mice studies using the replacement of the normal Igf2 gene for the knockout (modified gene which cannot be expressed), therefore not producing the Igf 2 protein, phenotypic differences were observed de- pending on parental origin of the knockout gene transmitted. Descendants were of normal size when the knockout gene was transmitted by the female and small when the knockout gene was transmitted by the male, showing the maternal allele imprinting of Igf2 (Efstratiadis, 1994). Imprinting has been described as a specific genetic phenomenon, which determines gene expression or repression depending on parental origin. This phenomenon consists of a reversible gamete-specific modification which occurs in some genes in parental generation and can lead to functional differences between maternal and paternal genomes in the descendants' diploid cells (Barlow, 1994).

Means and standard error of recovered ova and viable embryos obtained after superovulation protocol were coherent with the expected variation for these parameters in mice (Byers et al., 2006; Wohlres et al., 2006). The treatment efficiency shows that uncontrolled sources of variation (i.e., experimental error), remain important. Individual variation to superovulatory response is normally high in mice (Maffili et al., 2003) and also in other species (Hasler, 2003). Although there was great genetic homogeneity inside each group, factors such as estrous cycle period, which could directly influence results, cannot be controlled within the currently used protocols.

The correlation between number of corpora lutea identified in the ovaries and number of recovered ova shows that ovary visual inspection can be used to predict superovulatory results, avoiding flushing and embryo search in animals presenting poor ovarian response. There was no difference in the number of corpora lutea, ova or viable embryos among groups, and values were also within the range reported for endogamic strains (Wohlres et al., 2005; 2006). The comparison, however, may have been clouded by the instable nature of those variables, impairing characterisation of differences among groups. In fact, the elevated VC observed is one of the major problems of in vivo embryo production (Hasler, 2003). Superovulation also presents a direct negative effect on mice embryo viability (Ertzeid and Stonreg, 2001) but, as causes of the loss of developmental competence of these embryos remain unknown, it is uncertain if strain or heterosis has any effect on this parameter. Relative efficiency analysis, nevertheless, showed the highest recovery rate (ova/corpora lutea) and the second highest viable embryo/ova rate among groups in the CBA (pater- 
nal) x Swiss (maternal) mate. This group also presented the largest numeric mean values for ova and viable embryos.

In conclusion, the association of prolificity of dams strain and somatic development and superovulation response in the pups should be considered when a strategy for production of experimental F1 populations must be chosen, in particular when the aim is in vivo embryo production. The use of outbreed animals, however, did not reduce response variability to hormone treatments, as initially expected.

Acknowledgements - The authors thank Fiocruz for providing the animals and the CESJF Research Centre for the financial support.

\section{References}

ALVAREZ, RH., SILVA, MV., CARVALHO, JB. and BINELLI, M., 2005. Effects of inbreeding on ovarian responses and embryo production from superovulated Mantiqueira breed cows. Theriogenology, vol. 64, no. 8, p. 1669-1676.

ANDRADE, A., PINTO, SC. and OLIVEIRA, RS., 2006. Animais de laboratório: criação e experimentação. Rio de Janeiro: Fiocruz. 388 p.

BARLOW, PD., 1994. Imprinting: a gamete's point of view. Trends in Genetics, vol. 10, no. 6, p. 194-199.

BRAGGIO, MM., MARTINS, ARS. and VALERO, VB., 2003. Influência do manejo na produtividade e no desenvolvimento de camundongos (Mus musculus). Arquivos do Instituto Biológico, vol. 70 , no. 2, p. 149-153.

BYERS, SL., PAYSON, SJ. and TAFT, RA., 2006. Performance of ten inbred mouse strains following assisted reproductive technologies (ARTs). Theriogenology, vol. 65, no. 9, p. 1716-1726.

COWLEY, DE., POMP, D., ATCHLEY, R., EISEN, E. and HAWKINS-BROWN, D., 1989. The impact of maternal uterine genotype on postnatal growth and adult body size in mice. Genetics, vol. 122, no.1, p. 193-203.

DAVIS, JA. and LAMBERSON, WR., 1991. Effect of heterosis on performance of mice across three environments. Journal of Animal Science, vol. 69, no. 2, p. 543-550.

DIETERLEN-LIEVRE, F., CREUZET, S. and SALAUN, J., 2005. In vivo methods to analyze cell origins, migrations, homing, and interactions in the blood, vascular, and immune systems of the avian and mammalian embryo. Methods in Molecular Medicine, vol. 105, no.1, p. 215-230.

EAKIN, GS. and HADJANTONAKIS, AK., 2006. Production of chimeras by aggregation of embryonic stem cells with diploid or tetraploid mouse embryos. Nature Protocols, vol. 1, no. 3, p. $1145-1153$.

EFSTRATIADIS, A., 1994. Parental imprinting of autosomal mammalian genes. Current Opinion in Genetics and Development, vol. 4, no. 2, p. 265-280.

ERTZEID, G. and STORENG, R., 2001. The impact of ovarian stimulation on implantation and fetal development in mice. Human Reproduction, vol. 16, no. 2, p. 221-225.
EUCLIDES, RF., 1982. Sistema de análise estatística e genética (SAEG). Viçosa: Universidade Federal de Viçosa. 68 p.

FALCAO, AJS., MARTINS-FILHO, R., MAGNABOSCO, CU., BOZZI, R. and LIMA, FAM.,. 2001. Effects of inbreeding on reproductive and growth traits, and breeding values in closed Brown Swiss herd. Revista Brasileira de Zootecnia, vol. 30, no. 1, p. 83-92.

FESTING, MFW., 1976. Phenotypic variability of inbred and outbred mice. Nature, vol. 263, no. 5574, p. 230-232.

HASLER, J., 2003. The current status and future of commercial embryo transfer in cattle. Animal Reproduction Science, vol. 79, no. 3-4, p. 245-264.

HOLT, M., MEUWISSEN, T. and VANGEN, O., 2005. The effect of fast creating inbreeding on litter size and body weights in mice. Genetics, Selection, Evolution, vol. 37, no. 5, p. 523-537.

KURNIANTO, E., SHINJO, A., SUGA, D. and UEMA, N., 1999. Diallel cross analysis of body weight in subspecies of mice. Experimental Animals, vol. 48, no. 4, p. 277-283.

MAFFILI, VV., TORRES, CAA., CARVALHO, GR.,AMORIM, LS., MORAES, EA. and FURST, R., 2003. Efeito do horário de aplicação e dosagem de somatotropina bovina recombinante sobre o número, qualidade e taxa de desenvolvimento in vitro de embriões obtidos de camundongas superovuladas. Revista Brasileira de Reprodução Animal, vol. 27, no. 4, p. 684-689.

Mc PARLAND, S., KEARNEY, JF., RATH, M. and BERRY, DP., 2007. Inbreeding effects on milk production, calving performance, fertility, and conformation in Irish Holstein-Friesians. Journal of Dairy Science, vol. 90, no. 9, p. 4411-4419.

NELSON, JF., KARELUS, K., FELICIO, LS. and JOHNSON, TE., 1990. Genetic influences on the timing of puberty in mice. Biology of Reproduction, vol. 42, no. 4, p. 649-655.

NOTTER, DR., 1999. The importance of genetic diversity in livestock populations of the future. Journal of Animal Science, vol. 77, no. 1, p. 61-69.

STRINGFELLOW, DA. and SEIDEL, SM., 1998. Manual da Sociedade Internacional de Transferência de Embriões. Illinois: IETS. P. 112-113.

THOMPSON, JR., EVERETT, RW. and HAMMERSCHMIDT, NL., 2000. Effects of inbreeding on production and survival in Holsteins. Journal of Dairy Science, vol. 83, no. 8, p. 1856-64.

WOHLRES, S., PINTO, ISB., ARASHIRO, EKN. and VIANA, JHM., 2005. Efeito de diferentes protocolos superovulatórios sobre a produção de embriões em camundongos (Mus musculus) da linhagem Swiss. Acta Scientiae Veterinariae, vol. 33, no.1, p. 189.

WOHLRES, S., PINTO, ISB., BATISTA, RITP., FAZA, AP., PAIVA, FP., MAFFILI, VV., CAMARGO, LS. and VIANA, JHM., 2006. Qual a real eficiência dos protocolos de superovulação para a produção de embriões em camundongos de linhagens inbred? Acta Scientiae Veterinariae, vol. 34, no. 1, p. 584. 